Brit. J. industr. Med., 1960, 17, 247.

\title{
THE RELATION BETWEEN LUNG DUST AND LUNG PATHOLOGY IN PNEUMOCONIOSIS*
}

BY

\section{G. NAGELSCHMIDT}

From the Ministry of Power, Safety in Mines Research Establishment, Sheffield

(RECEIVED FOR PUBLICATION OCTOBER 7, 1959)

\begin{abstract}
Methods of isolation and analysis of dust from pneumoconiotic lungs are reviewed, and the results of lung dust analyses for different forms of pneumoconiosis are presented.

A tentative classification separates beryllium, aluminium, abrasive fume, and asbestos, which cause interstitial or disseminated fibrosis from quartz, coal, haematite, talc, kaolin, and other dusts, which cause a nodular or focal fibrosis which may change to forms with massive lesions. The data suggest that in the first, but not in the second, group the dusts are relatively soluble; only in the second group do amounts of dust and severity of fibrosis go in parallel for a given form of pneumoconiosis. In classical silicosis the quartz percentage is higher and the amount of total dust much lower than in coal-miners' pneumoconiosis. Mixed forms of both groups occur, for instance, in diatomite workers. The need for more research, especially in the first group, is pointed out.
\end{abstract}

Pneumoconiosis has been defined as "a diagnosable disease of the lungs produced by the inhalation of dust" (International Labour Organization, 1953) and in pneumoconiosis research the study of the dust found in the lungs after death is one of the means by which one tries to understand the development of the disease. Important advances in the technique of dust examination have been made in the past 20 years; $x$-ray diffraction methods were introduced for mineral analysis and are now well established; electron microscopy was used to examine the shapes of dust particles in situ or after their isolation, and to measure their size distributions. Techniques for such work are still being developed.

In order to yield the maximum information, the results of lung dust analyses need to be combined with pathological descriptions of the lungs and with a knowledge of the dust exposures. As dust exposures are usually of the order of decades such correlations are only possible to a limited extent and in certain cases. As the lung changes found appear to depend, among other things, on the concentration and composition of the deposited dust, it is necessary not only to ascertain the lung dust composition but also the total amounts of dust in the lungs. As it is not usually possible to use the complete lungs for

* A brief account of the main results of this paper was given at the International Pneumoconiosis Conference, Johannesburg, in February 1959, and will be published in its Proceedings. analysis this entails considerations of sampling.

This field is reviewed in the present paper. The first part deals with methods of sampling, isolation, and analysis of lung dust and with the way in which the results of the analyses can be expressed. In the second part separate disease entities, such as silicosis and pneumoconiosis of coal-miners, are reviewed on the basis of results from the literature and of work from our laboratory. The third part contains conclusions and speculations drawn from the data.

Methods

Sampling of Lungs.-Where only a small surgical specimen or a few grams of lung tissue are available for study, sampling is relatively easy, but if a complete pair of lungs is obtained at autopsy, the position is different. Very few studies have so far been concerned with details of the distribution of dust in different locations in the lung or in lymph nodes inside and outside the chest (Albertini, Brandenberger, and Rüttner, 1947; Gerstel, 1935). In general, so far, the main problem has been to determine the total amount of dust in the lungs and its composition.

Badham and Taylor (1938) discussed the problem of sampling. They considered it inadvisable to destroy the entire lung, as parts might be needed as medico-legal evidence in contentious compensation claims. In order to allow for disparities between the right and left lungs they divided each lung in the axillary plane into equal halves and used one half of each lung for analysis. King, Maguire, and Nagelschmidt (1956), in cooperation with Professor Gough, used one complete lung, usually the 
right, for analysis, while the left lung was preserved for histological examination, including the preparation of large sections (Gough and Wentworth, 1949). Lungs were used only if there were no gross dissimilarities between right and left lungs. Both methods may lead to some error.

Gerstel (1935) gave data about the dust content of right and left lungs which had been analysed separately. In 28 cases of silicosis without tuberculosis (the German use of "silicosis" is discussed below) from a variety of occupations, including mining of iron ore, coal, and pottery work, the total silica in both lungs ranged from 2-18 g. A calculation from his data showed that the mean value for the right lungs was only $3 \%$ higher than that for the left lungs, and that the standard deviation of the weight of dust in the right lung as a percentage of the total dust in both lungs, which can be taken as a measure of the uneven distribution of dust in right and left lungs, was $16 \%$.

Our own analyses of four pairs of lungs (kaolin, talc, electrode worker, and coal-miner), with massive lesions but without gross disparities between right and left lung, have shown practically no differences in composition, and differences of the order of 10-20\% in total dust expressed as a percentage of the dried right and left lung. The lung weights themselves differed more but, as they were known, allowance could be made for determining the total dust in both lungs.

At least a third, and preferably half, the lung material from a pair of lungs should be available for analysis if the total amounts of dust in them are to be determined. For a knowledge of dust composition alone smaller samples are adequate. Apart from the lungs themselves, the peribronchial and hilar lymph nodes also often contain dust, and their study can lead to additional information.

The type of sampling will always depend on the kind of information required. Gerstel (1935) sampled separately a number of silicotic lesions in a given pair of lungs in order to study the relation between the size of the fibrous mass and its silica content. Massive lesions and the remainder of the lung may be sampled separately in order to deduce the mode of formation of massive lesions from any differences that might be found in the composition of the two lung dust samples; the dust in the lymph nodes in the chest and elsewhere may also be analysed to study the effect of size on mobility within the lymphatic system.

Isolation of Lung Dust.-A variety of methods are available for separation of the dust from the lungs or gland tissue in which it is embedded. If chemical alteration of the dust by acid or alkali is to be minimized, purely mechanical methods can be used, as described by Sundius and Bygdén (1938). The wet lung tissue was grated with a file, the detritus washed with water, alcohol, and benzene, and fractions of different density were separated by centrifuging with heavy liquids. Although this method is the mildest one, it has the disadvantage that it only recovers part of the dust and is therefore not suitable for quantitative studies.

Another method which does not affect the dust and any calcification in the lung is the treatment of the lungs with water-free formamide at $135^{\circ} \mathrm{C}$. This method has been developed and described by Thomas and Stegemann (1954).

A method which is almost equally mild for minerals and suitable for coal of high rank, i.e. anthracite and steam coal, is treatment with concentrated $(30 \% \mathrm{w} / \mathrm{v}$.) $\mathrm{H}_{2} \mathrm{O}_{2}$ (Sundius and Bygdén, 1938). Fat is not destroyed by $\mathrm{H}_{2} \mathrm{O}_{2}$ and is removed by alcohol or acetone extraction either before or after the $\mathrm{H}_{2} \mathrm{O}_{2}$ treatment proper, preferably on both occasions. Coal of low rank, i.e. bituminous coal or lignite, is partially attacked by $\mathrm{H}_{2} \mathrm{O}_{2}$ and therefore it is not possible to use this technique for quantitative determination of coal dusts in general. Digestion of lung tissue with alkali (King and Gilchrist, 1945) is fairly satisfactory for the isolation of coal irrespective of its rank. The use of concentrated $\mathrm{HCl}$ for fresh and formalin-fixed (animal) tissue has been described by Wright (1957).

For mineral analysis the residue obtained after digestion of the lung with $\mathrm{H}_{2} \mathrm{O}_{2}$ can be ashed at $380^{\circ} \mathrm{C}$. and the ash extracted with suitable solvents to remove endogenous lung salts (Nagelschmidt and King, 1941). The extracting medium can be varied according to the type of lung dust. A prolonged extraction with cold, or a brief one with hot, $2 \mathrm{~N} \mathrm{HCl}$ removed most of the $\mathrm{Fe}_{2} \mathrm{O}_{5}$ and $\mathrm{P}_{2} \mathrm{O}_{5}$ from coal-miners' lung residues with losses of only a few per cent of the total $\mathrm{Al}_{2} \mathrm{O}_{3}$ and $\mathrm{SiO}_{2}$. Treatment with cold $\mathrm{N} / 10 \mathrm{HCl}$, used in the case of a talc residue, did not quite remove lung salts but left the talc unattacked (Fig. 1).

Another method, enzyme digestion (Hicks, McElroy, and Warga, 1937), is difficult to apply to formalinhardened tissue and is very slow. But, if ashing is permissible, it is also possible to ash the ground, dried lung powder in shallow layers in trays in an electric muffle at $380^{\circ} \mathrm{C}$. This requires more time but less labour than $\mathrm{H}_{2} \mathrm{O}_{2}$ treatment followed by ashing.

More destructive methods such as treatment with concentrated nitric acid followed by ignition of the dust at temperatures of the order of $600^{\circ} \mathrm{C} .-700^{\circ} \mathrm{C}$. have been used extensively in the past (Jones, 1933), but this can lead to some loss or alteration of the mineral dusts, and the results must be interpreted with caution (see below).

In conclusion, lung dust can be isolated in various ways and the choice will depend on the means available. A specialized laboratory which is equipped for formamide extraction may find this method the best, but very similar results can be obtained by $\mathrm{H}_{2} \mathrm{O}_{2}$ attack or combined methods. This can be illustrated by recent comparative work on coal-miners' lung dust analyses carried out jointly in two laboratories. Professor K. Thomas in Göttingen (Laboratory A) prepared four samples of vacuum-dried ground lung suitable for dust isolation by the formamide method and sent part of the material to the Safety in Mines Research Establishment in Sheffield (Laboratory B) where coal was determined by alkali digestion, and the mineral matter, in a separate sample, by ashing, followed by extraction with $2 \mathrm{~N} \mathrm{HCl}$. The results are given in Table 1 and show that similar values were obtained by different methods of analysis. 
FIG. 1.-Ash from talc lung.

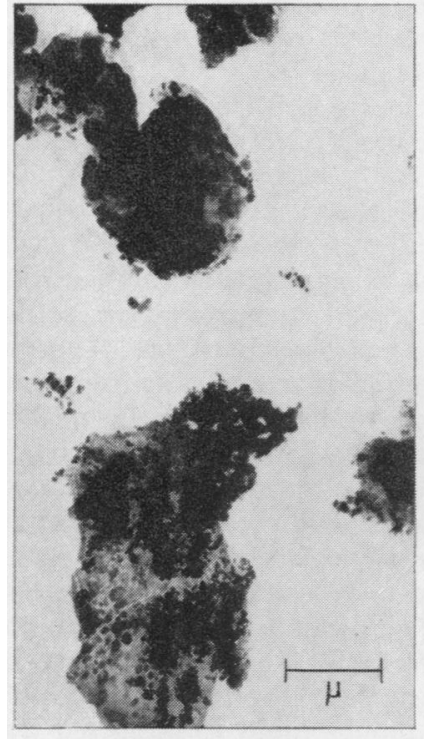

(a) Untreated; the talc plates are covered by endogenous lung salts.

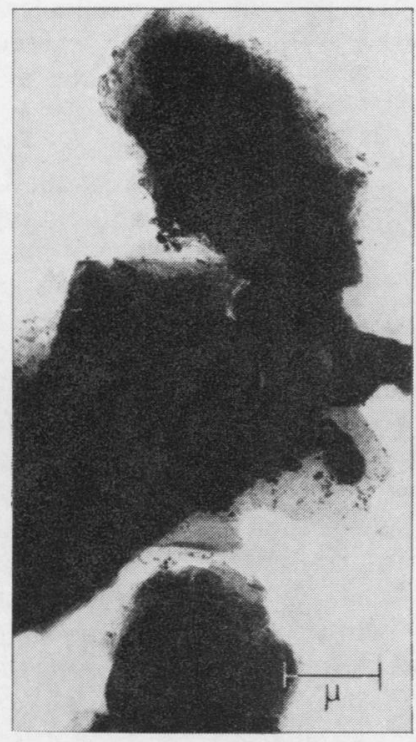

(b) Extracted with $0.2 \mathrm{~N} \mathrm{HCl}$; the thin talc plates are intact but a little endogenous lung salts are still present.

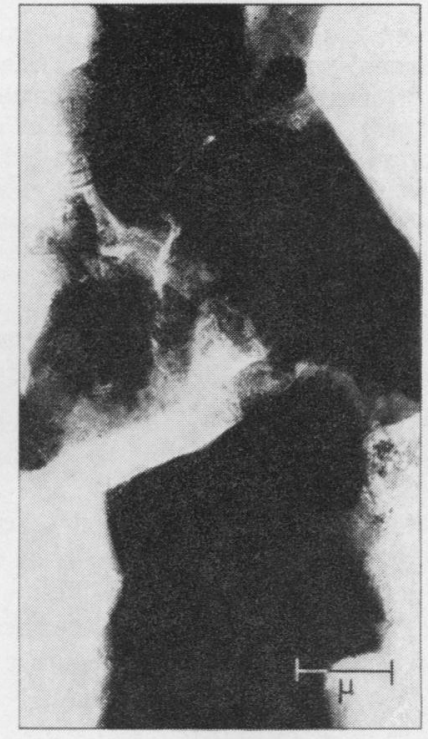

c) Extracted with $2 \mathrm{~N} \mathrm{HCl}$; the lung salts are completely removed but the thinnest talc plates are attacked.
TABLE 1

LUNG DUST ANALYSES CARRIED OUT BY DIFFERENT METHODS IN LABORATORIES A AND B

\begin{tabular}{|c|c|c|c|c|}
\hline \multirow{3}{*}{$\begin{array}{l}\text { Sample } \\
\text { Number }\end{array}$} & \multicolumn{4}{|c|}{ Percentage of Dried Lung } \\
\hline & \multicolumn{2}{|c|}{ Coal } & \multicolumn{2}{|c|}{ Mineral Matter } \\
\hline & $\mathbf{A}$ & B & $\mathbf{A}$ & B \\
\hline $\begin{array}{l}1 \\
2 \\
3 \\
4\end{array}$ & $\begin{array}{r}15.1 \\
5.7 \\
25.9 \\
15.5\end{array}$ & $\begin{array}{r}15.8 \\
5.3 \\
26.7 \\
15.8\end{array}$ & $\begin{array}{l}5 \cdot 2 \\
2 \cdot 20 \\
1.60 \\
0.90\end{array}$ & $\begin{array}{l}4.4 \\
1.94 \\
1.66 \\
0.98\end{array}$ \\
\hline
\end{tabular}

Composition of Lung Dust.-Lung residues usually consist of particles too small to be identifiable by petrological microscope techniques. The mineral composition of lung dust must therefore be determined by the methods developed for the analysis of clays and other materials of similar size. $X$-ray diffraction is the most important of these and can be used for quantitative analysis by film and diffractometer methods (Klug and Alexander, 1954). Although normal petrological microscope technique is not applicable, limited information can be obtained by dispersion staining (Schmidt, 1955). For quartz determination, chemical methods as accurate as $x$-ray methods have been developed (Nagelschmidt, 1956). Differential thermal analysis and infra-red absorption technique have also been used for quartz analysis. The extensive literature on this subject has been reviewed by Brasch (195́6).

The mineral composition of lung dust can be de- termined by direct methods and also by a complete chemical analysis. This requires a knowledge of the chemical composition of the individual members and its alteration by the method used for isolating the dust. For fairly accurate work a combination of more than one method, for instance $x$-ray diffraction and chemical analysis, is usually more successful than the use of one particular method.

For complete chemical analysis of the constituent oxides of a lung residue the semi-micro methods, used in silicate analysis, are appropriate (Shapiro and Brannock, 1956). A complete scheme has also been developed by Stegemann and Fitzek (1954); and Fitzek and Stegemann (1957).

Methods of Expressing the Results of Analysis.-The best way to present the results of lung dust analysis is to give the amounts, in grams, of the different constituents in any given lung. This can be done if the total lung weight is known and if a sufficiently large sample of it has been used either for dust isolation or for preparing homogeneous dried ground lung for analysis. If the results are only expressed as a percentage of dried lung they may depend to a considerable extent on the pathological condition of the lung (Collins and Dible, 1935). These authors describe a case in which the total silica in the right and left lungs was about the same $(0.69$ and 0.64 g.) but, because of pneumonic consolidation, the silica expressed as a percentage of dried lung was $0.53 \%$ in the pneumonic and $1.02 \%$ in the other lung. Similar considerations apply to the results when given as a 
percentage of ash. Calcification can affect the ash weight considerably and Collins and Dible (1935) give an example of a silicotic lung in which the ash content of different samples varied between 7 and $35 \%$ of dried lung according to the amount of calcification present.

These are, however, extreme examples. Results expressed as a percentage of dried lung are of value, especially if one is interested in averages and orders of magnitude for a number of analyses rather than in any single lung dust analysis.

\section{Different Forms of Pneumoconiosis}

The different forms of pneumoconiosis are difficult to classify. From the description of the kind of fibrosis the following appear to be distinguishable:

(1) Hyaline-nodular form (classical silicosis).

(2) Simple pneumoconiosis as seen, for example, in coal-miners in South Wales.

(3) Forms of fibrosis intermediate between (1) and (2) (as seen in haematite miners, foundry workers, ceramic workers, etc.). The German term "Mischstaubsilikose" probably covers groups 2 and 3.

(4) Diffuse interstitial fibrosis (as seen in asbestosis, aluminosis, Shaver's disease, and in chronic berylliosis).

In each of these four groups there is a range of lung changes which corresponds to increasing volume and severity of the fibrosis, culminating, at least for the first three groups, in the formation of areas of massive fibrosis.

Other classifications are sometimes based on the type of dust or the industry concerned. Asbestosis and classical silicosis are perhaps the best defined entities; pneumoconiosis of coal-miners is usually described as "silicosis" on the Continent, and the term "pneumoconiosis" as used for compensation purposes in Great Britain includes, for instance, silicosis of rock workers in coal-mines.

There exists a reasonable amount of information from lung dust analyses in classical silicosis and in the pneumoconiosis of coalworkers, and these will be dealt with first, followed by data on pneumoconiosis in the absence of quartz. Then follow results from red lungs in which iron oxide is the chief constituent, and for miscellaneous forms of lung dust disease, including asbestosis, where information is scanty. Emphasis will mainly be laid on lung dust analyses in the advanced stages of disease, where massive lesions predominate.

Classical Silicosis.-Silicosis is the best known of all the different forms of lung dust diseases. It has been studied and described in many industries and many countries. Perhaps the most detailed work was done in South Africa, where the introduction of mechanical drills towards the end of the last century caused a very large amount of silicosis in the gold mines of the Rand.

Silicosis is characterized by a specific type of lesion, the silicotic nodule (Simson, 1931; Belt, Ferris, and King, 1940), and it is caused by dusts which contain a substantial proportion of quartz. Although many studies of the lung dust in silicosis exist, there are only a few which can be used to correlate the amount and composition of the dust in the lungs with the pathological picture. Our data have been taken from three studies, one from South Africa, one from Australia, and one from Great Britain. In all three the pathological descriptions were unequivocal and corresponded to classical silicosis. Whole lungs were used for analysis, and from the methods of isolation described it was possible to estimate such losses of material as may have occurred. Furthermore, quartz determinations as distinct from total silica determinations were carried out in two of the series and in the third the proportions of quartz could be estimated from complete silicate analyses of the lung dust and other information obtained subsequently.

South African Gold-MINers.-Simson and Strachan (1935) isolated the mineral residues from 38 lungs of South African gold-miners by treatment with concentrated nitric acid, followed by ignition, a method introduced by Jones (1933). They recorded the weight of dust isolated, and in a later paper (Robertson, Simson, and Strachan, 1937) complete chemical analyses of 10 of these residues were given and interpreted in terms of minerals in the residues, which were essentially quartz and sericite. They classed the fibrosis simply as slight, moderate, marked, and very marked. Their second paper gave the analysis of an untreated lung ash sample; a comparison of the silica/alumina ratio of straight lung ash with the silica/alumina ratio of a nitric acid residue of the same lung showed that about $23 \%$ of the $\mathrm{Al}_{2} \mathrm{O}_{3}$, mainly from sericite, was lost in the nitric acid digestion. This had a slight effect on total recovery and tended to make the quartz estimate, which is based on the ratio $\mathrm{SiO}_{2}: \mathrm{Al}_{2} \mathrm{O}_{3}$, too high. The residues also contained from $1-10 \% \mathrm{P}_{2} \mathrm{O}_{5}$, indicating incomplete removal of phosphate from the lung salts.

For our calculations the amounts of dust found were used without further corrections on the assumption that the losses from the attack on the sericite balanced the gains due to incomplete removal of phosphate. As a check on the lung dust composition, residues were isolated by the $\mathrm{H}_{2} \mathrm{O}_{2}$ method in our laboratory from two lung specimens of South African classical silicosis, obtained from the museum of the Pathology Department of Sheffield University, and further information was obtained on quartz contents of lung dusts isolated by various methods recently in South Africa (Talbot, 1959). The quartz percentages calculated by Robertson et al. 
(1937) ranged from $46-66 \%$ of the total residues. These figures appear too high for the reason given above, and a range of $20-50 \%$ is more likely to be correct; this agrees with our own and recent South African $x$-ray diffraction analyses of residues prepared by $\mathrm{H}_{2} \mathrm{O}_{2}$ or other milder extraction methods. The chief constituent, apart from quartz, was the mica sericite. This mica occurs in the form of thin plates (Fig. 2). It had been described as fibrous previously (Jones, 1933) because plates on edge which look like fibres formed the bulk of the particles visible in canada balsam preparations under the polarizing microscope.

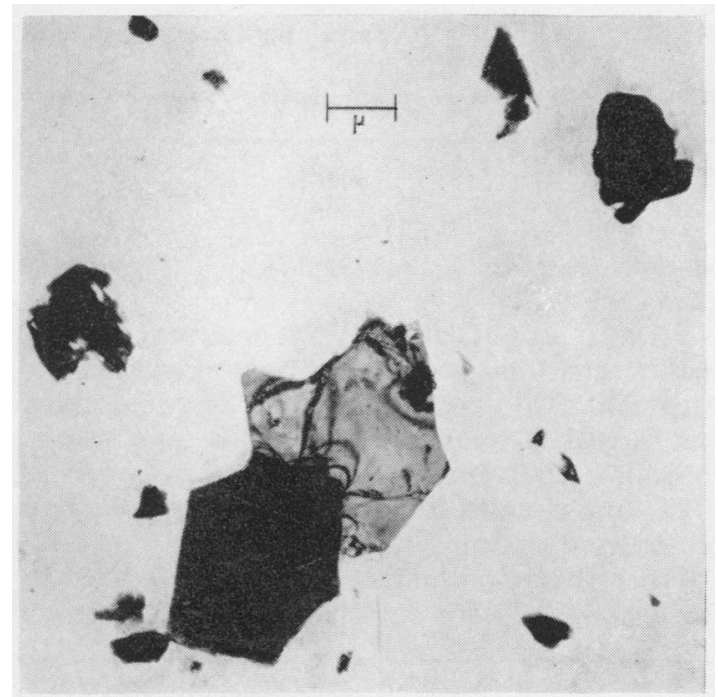

Fig. 2.-Sericite from lung dust of South African gold-miner with classical silicosis

Australian Metal Miners and Tunnel Workers.In a very valuable study Badham and Taylor $(1938,1941)$ gave the results of dust analyses of over 100 pneumoconiotic lungs, chiefly of coal-miners. These authors determined "free silica" by a chemical method, the "rational analysis" that had been developed in ceramic studies. Apart from determining total and free silica on samples of lung ash, they estimated "carbon" separately by alkali digestion of the tissues. They did not determine the total mineral residues. Their values for "free silica" may be $5-10 \%$ too low because the alkali treatment used to remove amorphous silica (resulting from decomposition of silicates by $\mathrm{H}_{2} \mathrm{SO}_{4}$ ) was rather drastic, but this effect is small and was ignored for our calculations. In order to obtain a value for the total mineral residue, their figures for "total combined silica" were doubled since many silicate minerals contain about $50 \%$ silica. This is a rough estimate, which would be approximately correct for mica, slightly high for felspar, and low in so far as free metal oxides may have been present in the lungs.

Badham and Taylor $(1938,1941)$ were chiefly interested in pneumoconiosis of coal-miners but amongst the lungs which they analysed were 26 in which the pathological description was that of silicosis, subdivided into moderate, marked, and massive. Their classification was as follows:

Moderate: Many fibrotic nodules, chiefly in the upper lobes, with or without small consolidations.

Marked: More numerous fibrotic nodules, especially in the upper lobes, with or without consolidations.

Massive: Fibrotic consolidations have largely taken the place of fibrotic nodulation.

A further subdivision of Badham and Taylor into "silicosis" (with more free than combined silica) and "siliceous type of pneumoconiosis" (with more combined than free silica) is based on the results of chemical analyses and not on histopathological observations, and for the present study their results for both groups were pooled.

Tin Miners and Granite Workers from Cornwall. -This series of lungs was studied by King et al. (1956) in order to contrast with the lungs of coal-miners from South Wales. Mineral residues were prepared by lowtemperature ashing and acid extraction, and were analysed by $x$-ray diffraction methods. Carbon in these lungs, determined by alkali digestion, was probably mainly soot or smoke from candles, acetylene lamps, and general air pollution.

Table 2 gives average values for the amounts of quartz, total minerals and, where possible, total dust including carbon, for various degrees of classical silicosis from the three above studies. The quartz content of the mineral portion and of the total lung dust has also been calculated.

In the series from South Africa the quartz percentage of the dust was assessed from the chemical analyses which had been carried out on all lungs with "very marked" fibrosis. The values ranged from $41-59 \%$ with a mean value of $48 \%$. As only one lung dust with "marked" and none with "slight fibrosis" had been analysed an average value of $50 \%$ was assumed for these and is indicated by an asterisk (*) in Table 2.

From Table 2 it will be seen that in classical silicosis, about 1-3 g. of quartz in 4-8 g. of total dust were found in the lungs. On an average, lungs with massive fibrosis contained more dust (and more quartz) than lungs with early or moderate silicosis but each grade of fibrosis showed a considerable range of dust values.

In rapidly developing silicosis the exposure time to quartz-rich dust is of the order of months rather than years and the dust concentrations are very high. Simson and Strachan (1935) included a few such lungs in their series. They obtained about $6 \mathrm{~g}$. of dust from single lungs of European gold-miners after 12 to 20 months of exposure and 13 and 
TABLE 2

AVERAGE AMOUNT AND COMPOSITION OF LUNG DUST IN CLASSICAL SILICOSIS

\begin{tabular}{|c|c|c|c|c|c|c|c|c|}
\hline \multirow[b]{2}{*}{ Fibrosis } & \multirow[b]{2}{*}{$\begin{array}{l}\text { Number } \\
\text { of Cases }\end{array}$} & \multicolumn{3}{|c|}{ Dust in Both Lungs } & \multirow{2}{*}{$\begin{array}{c}\text { Quartz } \\
\text { as } \\
\text { percentage } \\
\text { of } \\
\text { Siliceous } \\
\text { Minerals }\end{array}$} & \multirow{2}{*}{$\begin{array}{c}\text { Quartz } \\
\text { as } \\
\text { percentage } \\
\text { of } \\
\text { Total Dust }\end{array}$} & \multirow[b]{2}{*}{ Occupation } & \multirow[b]{2}{*}{ Reference } \\
\hline & & $\begin{array}{c}\text { Quartz } \\
\text { (g.) }\end{array}$ & $\begin{array}{c}\text { Quartz } \\
\text { and } \\
\text { Silicates } \\
\text { (g.) }\end{array}$ & $\begin{array}{l}\text { Total Dust } \\
\text { including } \\
\text { Carbon } \\
\text { (g.) }\end{array}$ & & & & \\
\hline Early to moderate & 14 & $0 \cdot 7$ & $2 \cdot 3$ & $4 \cdot 0$ & 31 & 19 & Tin miners and granite & King et al. (1956) \\
\hline Slight & 6 & $1 \cdot 0^{*}$ & $2 \cdot 1$ & ND & $50^{*}$ & ND & Gold-miners, South & Simson and Strachan \\
\hline Moderate & 6 & $1 \cdot 2$ & $4 \cdot 3$ & $7 \cdot 0$ & 36 & 23 & $\begin{array}{l}\text { Metal miners and } \\
\text { Sydney tunnel } \\
\text { workers }\end{array}$ & $\begin{array}{l}\text { Badham and Taylor } \\
\text { (1938) }\end{array}$ \\
\hline Marked & 7 & $1 \cdot 5^{*}$ & $3 \cdot 1$ & ND & $50^{*}$ & ND & Gold-miners, South & Simson and Strachan \\
\hline Massive & 20 & $2 \cdot 6$ & 5.9 & $7 \cdot 4$ & 49 & 33 & $\begin{array}{l}\text { Metal miners and } \\
\text { Sydney tunnel }\end{array}$ & $\underset{(1938)}{\text { Badham and Taylor }}$ \\
\hline Very marked & 6 & $\mathbf{3 \cdot 0}$ & $6 \cdot 1$ & ND & 48 & ND & $\begin{array}{l}\text { Gold-miners, South } \\
\text { Africa }\end{array}$ & $\begin{array}{l}\text { Simson and Strachan } \\
(1935)\end{array}$ \\
\hline
\end{tabular}

Indicates that quartz was assumed to be $50 \%$ of mineral dust, see text.

ND $=$ not determined.

$15 \mathrm{~g}$. of dust from single lungs of natives with unknown exposure histories. The dust composition appears to have been the same as in classical silicosis, as for two of the dusts the calculated quartz percentages were 42 and $60 \%$.

In two other cases of acute silicosis (Einbrodt, Graber, and Fitzek, 1957), the total lung dust, isolated by the formamide method, amounted only to 4 and $6 \mathrm{~g}$. and the quartz present in the dust was of the order of $40 \%$. It is not certain that the values refer to complete lungs.

To summarize, in classical silicosis from 1 to $3 \mathrm{~g}$. of quartz and from 4 to $10 \mathrm{~g}$. of total dust are found in the lungs with increasing degree of fibrosis. The quartz percentage of the dust may range from $20 \%$ upwards. The total dust present, expressed as a percentage of dried lung, is of the order of $1-4 \%$ and only rarely higher. In rapidly developing silicosis the quartz content of the lung dust is perhaps slightly higher, say above $30 \%$, and the total amounts of dust may be considerably larger than in typical silicosis.

Pneumoconiosis of Coalworkers.-Pneumoconiosis of coalworkers has been studied extensively in many countries.

The first series of over 30 analyses of South Wales coal-miners' lungs, published by Cummins and Sladden (1930), cannot be used for our purpose because no distinction between free and total silica was made; this series appears to have included a high proportion of rock workers in coal-mines with silicotic lung changes. It is possible, however, to use the figures for total (ash-free) coal isolated by nitric acid digestion of the lung tissue. The amounts of coal present in both lungs ranged from 5 to $119 \mathrm{~g}$. and the six highest values, for colliers and hard heading workers, were $119,104,97,77,52$ and 37 g. coal.

Badham and Taylor (1938) analysed over 40 coal-miners' lungs from various coalfields in Australia. Their method has been described above and their data were evaluated in the same way as those of silicotic lungs, i.e. the weights of combined silica were doubled to give the amount of siliceous minerals other than quartz.

The pathological lung changes were classified by Badham and Taylor as follows:

\begin{tabular}{c|c|c}
\hline $\begin{array}{c}\text { Pneumoconiosis } \\
\text { (Coal-dust Type) }\end{array}$ & $\begin{array}{c}\text { Stage of } \\
\text { Development }\end{array}$ & Lung Changes \\
\hline $\begin{array}{l}\text { Where the fibrosis } \\
\text { presents the } \\
\text { pat h ological } \\
\text { appearance of } \\
\text { perivascular fi- } \\
\text { brosis of coal- } \\
\text { dust type, with } \\
\text { nodulation or } \\
\text { consolidation. }\end{array}$ & Moderate & $\begin{array}{l}\text { Where perivascular fibrosis has } \\
\text { developed; a little irregular } \\
\text { fibrotic nodulation, chiefly in the } \\
\text { upper lobes. parked } \\
\text { Where perivascular fibrosis has } \\
\text { developed; irregular fibrotic } \\
\text { nodules, chiefly in the upper } \\
\text { lobes. } \\
\text { Where perivascular fibrosis of all } \\
\text { lobes has developed; irregular } \\
\text { nodulation, with or without } \\
\text { small consolidations. } \\
\text { Where fibrotic consolidations have } \\
\text { largely taken the place of } \\
\text { perivascular nodulation. }\end{array}$ \\
\hline
\end{tabular}

The lungs analysed included nine cases described as massive, eight as marked and seven as moderate fibrosis. Mean values were calculated and are given in the upper part of Table 3.

Coal-mining and handling covers a variety of occupations; changes in the composition of the dust for different occupation groups are reflected in the composition of the dust recovered from the lungs. This has been shown by King and Nagelschmidt (1945) in a study of 54 lung residues of coalworkers from South Wales. The proportions of rock dust decreased from $75 \%$ of the total lung dust for rock 
workers to $5 \%$ of the total dust for screen workers and trimmers. The largest group of men exposed to dust were colliers, and the lung dust found in colliers was intermediate in composition, containing on an average, $15 \%$ of rock dust (mainly mica and kaolin) and $2 \cdot 2 \%$ of quartz.

In a later study (King et al., 1956) whole lungs were analysed. The fibrosis of the lungs was assessed on the basis of the work of Belt and Ferris (1942):

Grade 2. Dust reticulation: a proliferation of reticulin fibrils, enclosing dust cells, of streaky distribution in the lung.

Grade 3. Reticular and mixed nodulation: focal indurations, rounded, angular, polygonal or stellate, composed of reticulin fibrils.

Grade 4. Confluent fibrosis: areas formed by the confluence of dust reticulation.

In this classification "reticular and mixed" nodulation is approximately equivalent to Badham's "moderate and marked" fibrosis and Belt's "confluent" to Badham's "massive" fibrosis. In the lower part of Table 3 average results are given of the lung dust analyses of colliers from South Wales. It will be seen that they are similar in composition to those of Badham and Taylor but that the amounts of dust found are higher. Amounts of dust exceeding $100 \mathrm{~g}$. per pair of lungs as reported by Cummins and Sladden (1930) may be rare but they do occur. The largest amount of dust found in a collier from South Wales, who died at the age of 36, was $149 \mathrm{~g}$. and Thomas (personal communication) isolated over $100 \mathrm{~g}$. of dust from the lungs of a Ruhr coal-miner. The few published analyses of Ruhr lung dusts give the impression that the dust composition is variable but often similar to that found in Australia and South Wales.

As a general conclusion it appears that in the lungs of colliers with massive fibrosis there are on an average 40 to $50 \mathrm{~g}$. of dust which contains over $80 \%$ coal; 10 to $15 \%$ of the dust is rock material and the quartz content of the lung dust is of the order of 2 to $3 \%$. The total dust averages about $15 \%$ of the dried lung weight.

Thus the total amounts of dust are about 10 times higher than those found in classical silicosis but the amounts of quartz are lower. King et al. (1956) drew attention to the fact that the lungs of silicotic tin and granite workers contained on an average less quartz than the lungs of coalworkers with massive fibrosis. Tables 2 and 3 of the present paper show that this is no longer true when the more advanced cases of silicosis from South Africa and Australia are compared with the coalworkers.

Quartz-free Lung Dusts.-Most mineral dusts in mines, quarries, or factories contain quartz, which is one of the most widespread minerals in the crust of the earth. There are, however, cases where quartz forms less than $0.5 \%$ of the total dust and where the resulting fibrosis of the lung is unlikely to have been caused by quartz. Such dusts have been found by us in the lungs of men exposed to kaolin, talc, mica, and a mixture of coal and coke in electrode manufacture.

In most of these cases advanced pneumoconiosis with massive lesions had been found by radiological examination and several had been severely disabled. The pathological descriptions included widespread, macroscopically nodular, fibrosis without the fibrous hyaline lesions seen in silicosis, and superimposed were the grosser changes: dense collagenous masses in one or both lungs which contained large amounts of dust. Histological evidence of tuberculosis was sometimes present. Several of these cases of pneumoconioses still await publication by the pathologists concerned and no further histological description will therefore be given, but the similarities of the lung changes to those seen in massive fibrosis of coalworkers were described as close or striking.

Amounts and composition of dust found in these cases are given in Table 4. The average amount of

TABLE 3

AVERAGE AMOUNT AND COMPOSITION OF LUNG DUST IN PNEUMOCONIOSIS OF COAL-MINERS

\begin{tabular}{|c|c|c|c|c|c|c|c|c|}
\hline \multirow[b]{2}{*}{ Fibrosis } & \multirow[b]{2}{*}{$\begin{array}{l}\text { Number } \\
\text { in Group }\end{array}$} & \multicolumn{4}{|c|}{ Dust in Both Lungs } & \multirow{2}{*}{$\mid \begin{array}{c}\text { Total Dust } \\
\text { as percentage } \\
\text { of } \\
\text { Dried Lung }\end{array}$} & \multirow{2}{*}{$\begin{array}{c}\text { Quartz } \\
\text { as percentage } \\
\text { of } \\
\text { Total Dust }\end{array}$} & \multirow[b]{2}{*}{ Reference } \\
\hline & & $\begin{array}{c}\text { Coal } \\
\text { (g.) }\end{array}$ & $\begin{array}{c}\text { Quartz } \\
(\mathbf{g} .)\end{array}$ & $\begin{array}{l}\text { Quartz and } \\
\text { Silicates } \\
\text { (g.) }\end{array}$ & $\begin{array}{c}\text { Total dust } \\
\text { (g.) }\end{array}$ & & & \\
\hline Moderate & 7 & $19 \cdot 1$ & 0.4 & $2 \cdot 6$ & $21 \cdot 7$ & $8 \cdot 2$ & $2 \cdot 4$ & Australia \\
\hline $\begin{array}{l}\text { Marked } \\
\text { Massive }\end{array}$ & $\begin{array}{l}8 \\
9\end{array}$ & $\begin{array}{l}23 \cdot 0 \\
32 \cdot 3\end{array}$ & $\begin{array}{l}0.4 \\
0.7\end{array}$ & $\begin{array}{l}2 \cdot 2 \\
5 \cdot 0\end{array}$ & $\begin{array}{l}25 \cdot 2 \\
37 \cdot 3\end{array}$ & $\begin{array}{l}10 \cdot 0 \\
15.6\end{array}$ & $\begin{array}{l}3.0 \\
1.8\end{array}$ & $\left(\begin{array}{l}\text { (Bandior, } \\
(1941)\end{array}\right.$ \\
\hline $\begin{array}{l}\text { Dust reticulation } \\
\text { Reticular and mixed nodulation } \\
\text { Confluent fibrosis }\end{array}$ & $\begin{array}{r}8 \\
9 \\
10\end{array}$ & $\begin{array}{l}13 \cdot 5 \\
34 \cdot 0 \\
49 \cdot 2\end{array}$ & $\begin{array}{l}0.58 \\
1.0 \\
1 \cdot 2\end{array}$ & $\begin{array}{l}2 \cdot 0 \\
4 \cdot 0 \\
5 \cdot 0\end{array}$ & $\begin{array}{l}15 \cdot 5 \\
38 \cdot 0 \\
54 \cdot 2\end{array}$ & $\begin{array}{r}5 \cdot 7 \\
12 \cdot 4 \\
14 \cdot 7\end{array}$ & $\begin{array}{l}3 \cdot 7 \\
2 \cdot 6 \\
2 \cdot 2\end{array}$ & $\begin{array}{l}\text { South Wales } \\
\text { (King et al., 1956) }\end{array}$ \\
\hline
\end{tabular}


TABLE 4

AMOUNT AND COMPOSITION OF DUST IN LUNGS WHICH CONTAINED ALMOST NO QUARTZ

\begin{tabular}{|c|c|c|c|c|c|c|}
\hline \multirow[b]{2}{*}{$\begin{array}{c}\text { Case } \\
\text { Number }\end{array}$} & \multirow[b]{2}{*}{$\begin{array}{c}\text { Main Dust } \\
\text { Constituent }\end{array}$} & \multicolumn{2}{|c|}{ Total Dust } & \multirow{2}{*}{$\begin{array}{l}\text { Quartz as } \\
\text { percentage of } \\
\text { of } \\
\text { Dried Lung }\end{array}$} & \multirow[b]{2}{*}{$\begin{array}{l}\text { Death due to } \\
\text { Pneumoconiosis }\end{array}$} & \multirow[b]{2}{*}{ Reference } \\
\hline & & $\begin{array}{l}\text { Estimated* } \\
\text { in Both } \\
\text { Lungs (g.) }\end{array}$ & $\begin{array}{c}\text { Percentage } \\
\text { of } \\
\text { Dried Lung }\end{array}$ & & & \\
\hline $\begin{array}{l}1 \\
2 \\
3 \\
4\end{array}$ & $\begin{array}{l}\text { Kaolin } \\
\text { Kaolin } \\
\text { Kaolin } \\
\text { Kaolin }\end{array}$ & $\begin{array}{l}96 \\
\text { ND } \\
\text { ND } \\
50\end{array}$ & $\begin{array}{l}26 \\
28 \\
26 \cdot 5 \\
35 t\end{array}$ & $\begin{array}{l}\text { Nil } \\
<0 \cdot 05 \\
<0 \cdot 05 \\
\text { Nil }\end{array}$ & $\begin{array}{l}\text { Yes } \\
\text { Yes } \\
\text { Yes } \\
\text { Yes }\end{array}$ & $\begin{array}{l}\text { Edenfield (unpublished) } \\
\text { Lynch and McIver (1954) } \\
\text { Lynch and McIver (1954) } \\
\text { Hale, Gough, King, and Nagelschmidt } \\
\text { (1956) }\end{array}$ \\
\hline $\begin{array}{r}5 \\
6 \\
7 \\
8 \\
9 \\
10\end{array}$ & $\begin{array}{l}\text { Talc } \\
\text { Talc and chlorite } \\
\text { Talc and chlorite } \\
\text { Talc and kaolin } \\
\text { Muscovite } \\
\text { Coke and coal }\end{array}$ & $\begin{array}{r}68 \\
58 \\
45 \\
\text { ND } \\
\text { ND } \\
75\end{array}$ & $\begin{array}{l}16 \cdot 5 \\
14,23+ \\
13 \cdot 2 \\
10 \cdot 0 \\
12 \cdot 0 \\
22 \cdot 0\end{array}$ & $\begin{aligned}<0.05 \\
<0.02 \\
<0.02 \\
<0.1 \\
0.01 \\
<0.02\end{aligned}$ & $\begin{array}{l}\stackrel{?}{\text { Yes }} \\
\text { Yes } \\
\text { No } \\
\text { No } \\
\text { Yes }\end{array}$ & $\begin{array}{l}\text { Hunt (1956) } \\
\text { Griffith (unpublished) } \\
\text { Griffith (unpublished) } \\
\text { McLaughlin, Rogers, and Dunham (1949) } \\
\text { Walker (unpublished) } \\
\text { Watson, Black, Doig, and Nagelschmidt } \\
\text { (1959) }\end{array}$ \\
\hline 11 & Coke and coal & 100 & 34 & $<0.01$ & Yes & Watson et al. (1959) \\
\hline
\end{tabular}

* From dry weight of one or both lungs.

$\dagger$ On massive lesion.

¥ Values for right and left lungs respectively.

ND $=$ Not determined.

dust was about 74 g. or $20 \%$ of dried lung weight, values which are even higher than those found in colliers with massive fibrosis. A lung dust analysis of a German electrode maker, very similar to Cases 10 and 11 in Table 4, has recently been described by Otto and Einbrodt (1958). They found about $90 \mathrm{~g}$. of carbon in both lungs; the dust contained $3 \%$ total ash and approximately $0.1 \%$ quartz which could only be identified with difficulty by phase contrast microscopy on ashed lung sections after formamide treatment.

Lungs containing predominantly Iron Oxide.-For convenience, data on haematite miners and foundry workers are given together and one ochre lung is included.

HAEMATITE LUNGS. - The red lungs of haematite miners from Cumberland described and illustrated by Stewart and Faulds (1934) form a strong contrast to the black lungs of coal-miners. Chemical but no mineral analyses of the lung ash of such haematite miners were given by Faulds (1957).

One hundred and forty four fibrotic lungs with or without tuberculosis or carcinoma contained an average of $5 \% \mathrm{Fe}_{2} \mathrm{O}_{3}$ and $1.2 \% \mathrm{SiO}_{2}$ as a percentage of dried lung. The average dried lung weight was about $400 \mathrm{~g}$. From individual analyses given by Faulds and Stewart (1956) the estimated amounts of iron oxide per pair of lungs varied between 9 and $45 \mathrm{~g}$.

Samples of some 70 of these lungs are being analysed in our laboratory but this work is not yet complete. The average lung dust composition is approximately $80 \%$ haematite, $5 \%$ quartz, and $15 \%$ mica. The estimated amounts of dust found in the lungs with massive fibrosis classed as +++ range from 30 to $85 \mathrm{~g}$. This, as well as the histological descriptions, suggests that the disease is more similar to pneumoconiosis of coal-miners than to classical silicosis although the quartz percentage of the lung dust is about two to three times as high as that of coal-miners.

In contrast to these observations, Gerstel (1941) found that the total iron oxide $\left(\mathrm{Fe}_{2} \mathrm{O}_{3}\right)$ in the lungs of silicotic coal-miners, lead-, and zinc-miners, and ceramic workers ranged between 0.4 and $5 \mathrm{~g}$.; he found similar values for silicotic iron-ore-miners from the Siegerland. He concluded from his observations that inhaled iron oxide was capable of being excreted from the lungs. It is not likely that inhaled haematite is removed at a greater rate from the lungs than coal, quartz, or kaolin and it is more likely either that the airborne dust in the Siegerland mines did not contain much iron oxide or that Gerstel failed to analyse lungs which had accumulated it.

FOUNDRY WORKERS. - The fibrotic lung changes of foundry workers range from classical silicosis to what Harding, Gloyne, and McLaughlin (1950) describe as "mixed dust pneumoconiosis"; "a perivascular and peribronchial fibrosis consisting of collagen, reticulin, dust and cells, growing into large irregular patches in the later stages of the disease but without the sharply defined whorled nodule of classical silicosis.... The picture at times resembles that in South Wales coalworkers". In a later paper, McLaughlin and Harding (1956) gave average values for total and free silica, the latter determined by a chemical method (Trostel and Wynne, 1940) for 65 lungs of foundry workers, classified into four stages of fibrosis, viz., massive, nodular, minimal, and nil. Unpublished figures for 
total iron oxide for these lungs were obtained from Dr. H. E. Harding, and by doubling the values for combined silica, approximate values for total mineral dust (minus carbon) and for the quartz percentage of this dust were obtained. These figures are given in Table 5. In massive fibrosis the total dust was $2 \cdot 6 \%$ of dried lung and even if one assumes a high average dry weight of $400 \mathrm{~g}$. for these lungs, the total dust would only be about $11 \mathrm{~g}$. Quartz in the lung dust, however, was $15 \%$. These values suggest that the disease of foundry workers in these cases may have been more similar to classical silicosis than to the pneumoconiosis of haematite miners.

The lungs of a fettler (X5371) who had worked for 28 years in an iron foundry and lived for eight years after the end of his dust exposure were analysed in our laboratory. His lung fibrosis was, according to Dr. H. E. Harding, who supplied the material, intermediate between classical silicosis and mixed dust fibrosis. The lung dust contained $45 \%$ quartz and $15 \%$ cristobalite, the balance being made up of iron oxides, mainly haematite. The total dust was $7 \cdot 4 \%$ of dried lung and amounted to about $15 \mathrm{~g}$. in both lungs. According to animal experiments cristobalite is slightly more fibrogenic than quartz. It can be formed by the interaction of molten iron with fine-grained quartz or clay and has also been found by us in foundry dusts. The figure for free silica as a percentage of dried lung in this case was over three times higher than the highest value found by McLaughlin and Harding (1956), and the pathological picture of classical silicosis might have been expected on the basis of the lung dust analysis.

OCHRE.-As a contrast the case of an ochre grinder (X5700) may be mentioned who had worked at or near a pigment mill grinding iron oxides and hydroxides. He had been exposed to this dust for over 40 years and had died at the age of 66 , seven years after ending his dust exposure. According to Dr. H. E. Harding his illness and death were unrelated to the dust exposure. The lungs showed "focal red pigmentation associated with doubtful focal emphysema and there was definite but not severe fibrosis of mixed dust type". The lung dust consisted of $70 \%$ iron oxide and hydroxide, about $20 \%$ kaolin, with some mica, and $10 \%$ carbonaceous material. There was less than $1 \%$ of quartz in the dust.
The total dust amounted to $10 \%$ of dried lung or about $17 \mathrm{~g}$. in both lungs. This man had more dust in his lungs than the iron fettler (X5371) and far more than any of McLaughlin's and Harding's (1956) foundry workers with massive fibrosis; in the absence of quartz, the fibrosis was not severe. This case is also interesting because it suggests that Harding's "mixed dust pneumoconiosis" may arise in the almost complete absence of quartz.

The quartz content of the lung dust seems to increase in the order ochre worker, haematite miners, foundry workers; the silicotic features of the fibrosis appear to follow the same trend.

Berylliosis, Aluminosis, Shaver's Disease, and Asbestosis.-These forms of pneumoconiosis are grouped together because the fibrosis is described as interstitial rather than nodular, although the chronic fibrosis in berylliosis also shows granulomata. Aluminosis and Shaver's disease have a further similarity in the frequent occurrence of spontaneous pneumothorax.

BERYLliosis. - The amounts of beryllium found by spectrographic analyses of lung ash in a few cases of chronic berylliosis were of the order of $20 \mu$ g. per $100 \mathrm{~g}$. wet lung (Machle, Beyer, and Tebrock, 1949), and for one case they were given as $0.16 \mathrm{mg}$. for the whole lung (Martland, 1950). There are very few analyses published, but they suggest that $1 \mathrm{mg}$. of beryllium oxide may be the upper limit for the total amount of dust found in the lungs in chronic berylliosis.

Aluminosis.-Unfortunately, no data exist for the various cases of aluminosis reported from Germany by Goralewski (1950) except that aluminium could be demonstrated in the lungs by fluorescence microscopy. In one case, recently reported from Britain (Mitchell, 1959), where there was extensive diffuse fibrosis of the lungs, the average aluminium content of the dried lung was given as $0.03 \%$. The total weight of the lungs had not been recorded but even assuming it to have been $400 \mathrm{~g}$., the total dust would only be $120 \mathrm{mg}$. of aluminium (Al) or $250 \mathrm{mg}$. of alumina $\left(\mathrm{Al}_{2} \mathrm{O}_{3}\right)$ in both lungs.

TABLE 5

AVERAGE AMOUNT AND COMPOSITION OF DUST IN FOUNDRY WORKERS' LUNGS (MCLAUGHLIN AND HARDING, 1956)

\begin{tabular}{|c|c|c|c|c|c|c|}
\hline \multirow{2}{*}{ Fibrosis } & \multirow{2}{*}{ No. of Lungs } & \multicolumn{4}{|c|}{ Percentage of Dried Lung } & \multirow{2}{*}{$\begin{array}{c}\text { Quartz } \\
\text { as percentage of } \\
\text { Total Dust }\end{array}$} \\
\hline & & $\mathrm{Fe}_{2} \mathrm{O}_{3}$ & Quartz & Silicates & Total Dust* & \\
\hline $\begin{array}{l}\text { Nil } \\
\text { Minimal } \\
\text { Nodular } \\
\text { Massive }\end{array}$ & $\begin{array}{r}9 \\
26 \\
18 \\
11\end{array}$ & $\begin{array}{l}0.80 \\
0.70 \\
1.05 \\
1.2\end{array}$ & $\begin{array}{l}0 \cdot 10 \\
0 \cdot 22 \\
0 \cdot 31 \\
0 \cdot 38\end{array}$ & $\begin{array}{l}0.22 \\
0.54 \\
0.68 \\
1 \cdot 0\end{array}$ & $\begin{array}{l}1 \cdot 1 \\
1 \cdot 5 \\
2 \cdot 0 \\
2 \cdot 6\end{array}$ & $\begin{array}{r}9 \\
15 \\
15 \\
15\end{array}$ \\
\hline
\end{tabular}

* Excluding carbon. 
Shaver's Disease.-Jephcott (1948) has given analyses of the ash of six cases of Shaver's disease. The lung dust was similar to the fume which consisted mainly of spherical particles of amorphous alumina and silica, with minor amounts of $\alpha$ and $\gamma-\mathrm{Al}_{2} \mathrm{O}_{3}$.

The average alumina content was $1.95 \%$ and the average silica $1.61 \%$ of dried lung. As these two oxides were the main fume or dust constituents, the total lung dust was of the order of $3.6 \%$ of dried lung (with a range of $2-4.9 \%$ ). There was no clear relation between the amount of dust and length of dust exposure although the case with the longest exposure had the lowest amount of dust. No data exist by which a relation between the amount of dust and the severity of fibrosis can be assessed.

AsBestosis.-Lung dust analyses in asbestosis are surprisingly rare. Sundius and Bygdén (1937) gave a very detailed account of the lung dust analysis of one case of asbestosis. They estimated the total mineral dust in both lungs as $2.8 \mathrm{~g}$., half of it being hornblende asbestos, the remainder rutile, quartz, and carbonates.

More extensive data were given by Knox and Beattie (1954) who ashed representative portions of both lungs from 27 cases and extracted the ash with dilute hydrochloric acid. They found, on an average, that the mineral dust amounted to $0.4 \%$ of dried lung without any clear increase in the amount of dust with increasing severity of fibrosis, but with a decrease in dust in proportion to the period between the end of dust exposure and death. Hilum and pleura contained as much as, or more, dust than the lungs on a percentage basis.

With an assumed dry weight of 300 to $400 \mathrm{~g}$. for lungs, hilum, and pleura, the total amounts of dust found by Knox and Beattie (1954) would be of the order of 1.5 to $3 \mathrm{~g}$., in good agreement with the data of Sundius and Bygdén (1937).

A lung dust analysis of a case of severe asbestosis (X5747) (given to us by Dr. D. Rivers of the Pneumoconiosis Research Unit) carried out recently in our laboratory showed very little dust corresponding to $0.8 \%$ dried lung, or $1.3 \mathrm{~g}$. in the right lung, but no asbestos mineral could be identified by $x$-ray diffraction nor could fibres be seen by optical or electron microscopy in the isolated lung dust.

Asbestos is a general term which covers chrysotile $\left(\mathrm{Mg}_{3} \mathrm{Si}_{2} \mathrm{O}_{5}(\mathrm{OH})_{4}\right)$ and several hornblende varieties. As far as we know, no positive identification of chrystotile in a human lung with asbestosis has so far been published, and more information on the amount and composition of the lung dust in asbestosis is needed.

\section{Discussion}

It has been shown in the preceding section that severe disabling fibrosis of the lungs is associated with dusts of different composition and in different amounts. At one end of the scale, in chronic berylliosis, there may be only $1 \mathrm{mg}$. or less of beryllium in the lungs; at the other end of the scale there may be over $100 \mathrm{~g}$. of dust with little or no quartz.

When a man is breathing dusty air, a certain proportion of dust particles, depending on their aerodynamic "size", penetrate the upper respiratory tract and are deposited in the deeper parts of the lung. This initial deposition varies with the size of dust and breathing rate and is amenable to calculation (Findeisen, 1935) and experiment (Altshuler, Yarmus, Palmes, and Nelson, 1957; Dautrebande, Beckmann, and Walkenhorst, 1957; 1958). But dust deposition is followed by dust clearance, mainly by migration of dust-laden phagocytes up the bronchial tree, and to some extent by transport to the lymph glands. Accumulation of dust in the lungs only takes place in so far as these two defense mechanisms are insufficient, and it will depend further on the rate at which the dust can be dissolved.

Soluble Dusts.-Dusts appear to be completely insoluble or more or less soluble inside dust cells or in tissue fluids. Test tube experiments give only limited guidance on this point because the rate at which the dissolving fluid extracts the dust deposit, the diffusion rate of the dissolving components, and even the $p \mathrm{H}$ at which the reaction takes place, are unknown. Animal experiments are intended to bridge this gap, but their value is somewhat limited on account of the short lifespan of the smaller animals generally used. Outstanding examples of slightly soluble dusts which apparently do not cause pneumoconiosis in men, in spite of heavy dust exposure histories, are calcite (Bridge Davis and Nagelschmidt, 1956) and gypsum and cement (Sander, 1958). Impurities in calcite and gypsum and the raw material used in cement manufacture can, however, cause pneumoconiosis (Doig, 1955; Doerr, 1952).

But it appears likely that certain slowly dissolving constituents can cause a particular type of fibrosis which is neither focal nor nodular and is usually described as disseminated or interstitial. Such interstitial fibrosis is the common factor in berylliosis, aluminosis, Shaver's disease, and asbestosis. From the point of view of the lung dust analysis, the following appear to be criteria for soluble dusts:

(1) An obvious disproportion between the amount of 
dust and the amount of fibrosis (suggested by the figures for berylliosis and aluminosis).

(2) A gross lack of parallelism between the amount of dust and the degree of tissue change for a given type of dust.

(3) An obvious decrease in the amount or size of dust with an increasing length of time between the end of dust exposure and death.

(4) Differences in composition between airborne dust and lung dust.

The data of Knox and Beattie (1954) suggest that Nos. 2 and 3 above are present in asbestosis; there is also limited evidence for No. 4, as the bulk of asbestos dust in manufacture is chrysotile but no chrysotile has been found in the few asbestosis lungs which have been examined mineralogically.* Present information is clearly insufficient but there are grounds for supposing that the breakdown products of chrysotile and hornblende may cause the interstitial fibrosis of mainly the lower lobes which characterizes asbestosis, rather than the mechanical damage by the larger fibres, which is at present believed to be its cause. If this were true, the silicic acid rather than the magnesium hydroxide released in the breakdown of chrysotile or hornblende would be likely to cause this fibrosis. It also appears possible that in aluminosis and in Shaver's disease dust solubility plays a role, and that aluminium ions and polysilicic acid dissolving from the silica fume in Shaver's disease, precipitate proteins and cause the fibrosis which is, as in asbestosis, interstitial rather than nodular. Aluminosis and Shaver's disease were mainly produced under abnormal dust conditions during the second world war and they appear at present to be rare. Arc furnace fumes in alloy or abrasive manufacture or in other industries may, however, still cause this form of disease.

The correlation of slow solubility of certain dusts and the appearance of diffuse interstitial fibrosis is at present hardly more than a speculation based on the scanty data given above. More lung dust analyses are required before it can be accepted as correct and it should also be supported by physicochemical studies and animal experiments. In contrast, the data for insoluble dusts are far more copious.

Insoluble Dusts.--If the lung dust has approximately the same composition as the airborne dust of similar size and if increasing severity of fibrosis corresponds to increasing amounts of dust, irrespective of the length of period between the end of

* Knox and Beattie (1960) have recently observed the presence of chrysotile in asbestosis bodies obtained from human lungs. (Symposium on Inhaled Particles and Vapours, Oxford, March 29 to April 1.1960. dust exposure and death, then it is likely that the fibrosis is due to the continued presence of the dust itself rather than to the effects of a dissolving constituent or of its residue. This appears to be the case in classical silicosis, in the pneumoconiosis caused by quartz-free dusts, and in the diseases intermediate between them such as coalworkers' and haematite miners' pneumoconiosis. Quartz has a specific capacity to cause excessive formation of collagen which is not due to its limited initial solubility (Englebrecht, Yoganathan, King, and Nagelschmidt, 1958; Marks and Nagelschmidt, 1959) and it is tempting to relate this extra fibrogenic power of quartz to the smaller amounts of dust found in classical silicosis and to conclude that, on average, the higher the quartz percentage the lower the total amount of dust collected in the lungs before disability makes an end to further uptake of dust.

In Fig. 3 the average amount of quartz in lungs with massive fibrosis is plotted against the average amount of total dust for gold-miners with classical silicosis, for coal-miners, and for the quartz-free lung dusts. Further areas are also given for foundry workers and haematite miners. It may be an accident that the three areas for the first group lie on a straight line, but the general trend is probably not accidental. The broken line separates on the left the field in which quartz is above $18 \%$ of the total dust, as is almost invariably found in classical silicosis, and on the right the field where quartz is less than $18 \%$ of the total dust. It would seem obvious that there cannot be such a sharp boundary but the further one moves away from it to the right, the more does the lung pathology, in the parts in which there are no massive lesions, depart from collagenous nodules and the more does it approach that of simple pneumoconiosis as described for instance by Heppleston (1947). The existence of the boundary can perhaps be explained by assuming that the stimulus to the excessive collagen formation requires a quartz concentration inside phagocytes which is not reached if the quartz percentage of the dust falls too low. The position of the area for haematite miners may suggest a partial inhibition of the fibrogenic activity of quartz by iron oxide.

The data given in Tables 2 to 5 demonstrate that, on average, the amounts of dust and the severity of tissue changes in lungs are well correlated for insoluble dusts. How this can be reconciled with the conception that classical silicosis and most forms of massive fibrosis are progressive in the sense that a given amount of dust will go on producing more and more collagen or increasing areas of massive fibrosis as time goes on can probably be explained by two factors; the usually slow development of the disease, and the selection of lungs that become available for 


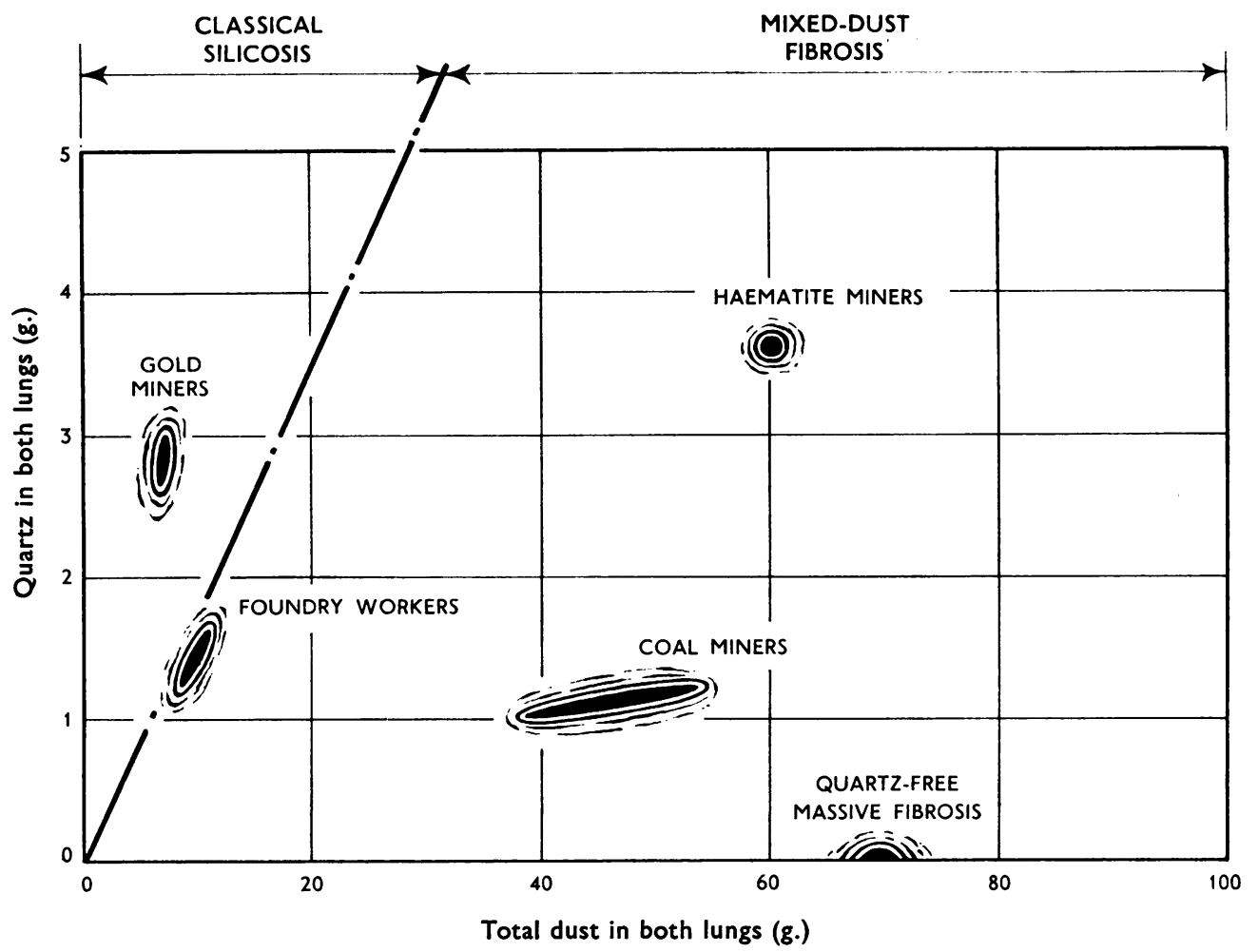

Fig. 3.-Average values of total dust and quartz in lungs with advanced forms of different dust diseases.

study. Cases of classical silicosis with negligible amounts of fibrosis in the presence of large amounts of dust are unlikely to be found because the uptake of dust is usually so slow that the development of fibrosis keeps pace with it; and in any case such cases would not become available for analysis until fibrosis had developed sufficiently to cause death. It is only in the so-called "acute" or rapidly developing silicosis that a disproportion between dust and fibrosis might occur.

Similar considerations apply to the massive fibrosis (PMF) of coal-miners. This is believed to be the result of an infective process, probably mainly tuberculosis, in a dust-ridden lung, and is believed not to require any further uptake of dust. As the chances of development of PMF are higher the more advanced the simple pneumoconiosis is (Cochrane and Miall, 1956), it is not surprising that in an earlier study (King et al., 1956), more dust on average, was found in the lungs of coal-miners with PMF than in lungs with the most advanced type of simple pneumoconiosis (see Table 3).

However, recent work based partly on lung dust analyses of coal-miners, killed in accidents, who had been examined radiologically two years or less before death, showed, on average, for radiological stage 3 of simple pneumoconiosis, $53 \mathrm{~g}$. of total dust in both lungs, with four cases out of nine ranging from 60 to $88 \mathrm{~g}$. (Rivers, Wise, King, and Nagelschmidt, 1960).

Amongst 15 further pit accidents there were four more cases of simple pneumoconiosis which had between 25 and $65 \mathrm{~g}$. of dust. Unless special efforts had been made to obtain such accident cases which may be considered as a random selection of coalworkers, similar lungs would probably not have been analysed until PMF had developed and had caused or contributed to their death.

Mixed Dusts. - In the foregoing, a distinction has been drawn between soluble dusts which cause interstitial, and insoluble dusts, which cause nodular fibrosis of the lungs. Mixed forms have been described especially in diatomite workers, where the dust, and the lung residues, consist of a mixture of quartz and sometimes cristobalite, and much amorphous silica (Löblich, 1958). It is possible that polysilicic acid resulting from the dissolution 
of the amorphous silica causes the interstitial, and quartz and cristobalite the nodular fibrosis in these lungs. This again requires support by further laboratory studies.

Thanks are due to a number of pathologists who provided lung material and information, especially to Drs. J. Gough, F. E. D. Griffith, J. S. Faulds, H. E. Harding and D. Rivers, and to my colleagues at the Safety in Mines Research Establishment, Drs. R. L. Gordon and K. Wheatley, Messrs. O. G. Griffin, G. W. Harris, L. Mardlin and M. S. Paterson, and Misses E. S. Nelson and J. Vincent, who painstakingly carried out many analyses, to Mr. B. A. Maguire for statistical help, and to Dr. J. C. Gilson for helpful criticism in the preparation of the manuscript. I am grateful to Professor K. Thomas of Göttingen for his participation in the chemical analyses of dusts and for his permission to publish the results.

The paper is published by permission of the Ministry of Power, and the illustrations are Crown Copyright.

\section{REFERENCES}

Albertini, A. von, Brandenberger, E., and Rüttner, J. R. (1947). Vjschr. naturf. Ges. Zürich, 92, Beih. 3 and 4, p. 143.

Altshuler, B., Yarmus, L., Palmes, E. D., and Nelson, N. (1957). A.M.A. Arch. industr. Hlth, 15, 293.

Badham, C., and Taylor, H. B. (1938). Annual Report, Department of Public Health, N.S.W., 1936, p. 100.

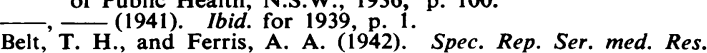
T. H., and Ferris, A. A. (1942). Spec. Rep. Ser. med. Res.
Coun. (Lond.), No. 243, Pt. C, p. 203. H.M.S.O., London. Coun. (Lond.), No. 243, Pt. C, p. 203. H.M.S.O., Lon
and King, E. J. (1940). J. Path. Bact., 51, 263.

Brasch, J. K. (1956). Amer. industr. Hyg. Ass. Ouart., 17, 65.

Bridge Davis, S., and Nagelschmidt, G. (1956). Brit. J. industr. Med., 13, 6 .

Cochrane, A. L., and Miall, W. E. (1956). Brit. med. J., 1, 1193.

Collins, D. H., and Dible, J. H. (1935). J. Hyg. (Lond.), 35, 64.

Cummins, S. L., and Sladden, A. F. (1930). J. Path. Bact., 33, 1095.

Dautrebande, L., Beckmann, H., and Walkenhorst, W. (1957) A.M.A. Arch. industr. Hlth, 16, 179.

$-, \frac{1}{\text { p. } 297 \text {. Dietrich Steinkopff, Darmstadt. }}$ Doig, A. T. (1955). Brit. J. industr. Med., 12, 206

Doerr, W. (1952). Virchows Arch. path. Anat., 322, 397.

Einbrodt, H. J., Graber, H., and Fitzek, J. (1957). Beitr. SilikoseForsch., Heft., 47, p. 19.

Englebrecht, F. M., Yoganathan, M., King, E. J., and Nagelschmidt, G. (1958). A.M.A. Arch. industr. Hlth, 17, 287.

Faulds, J. S. (1957). J. Clin. Path., 10, 187. (August)

Findeisen, W. (1935). Pflüg. Arch. ges. Physiol., 236, 367.

Fitzek, J., and Stegemann, H. (1957). Beitr. Silikose-Forsch. Heft., 47 , p. 39

Gerstel, G. (1935). Arch. Gewerbepath. Gewerbehyg., 6, 304.

- (1937). Ibid., 8, 277.

- (1941). Ibid., 10, 616.
Goralewski, G. (1950), Die Aluminiumlunge (Arbeitsmedizin, Heft 26), Barth, Leipzig.

Gough, J., and Wentworth, J. E. (1949). J. roy. micr. Soc., 69, 231.

Hale, L. W., Gough, J., King, E. J., and Nagelschmidt, G. (1956) Brit. J. industr. Med., 13, 251 .'

Harding, H. E., Gloyne, S. R., and McLaughlin, A. I. G. (1950) In Industrial Lung Diseases of Iron and Steel Foundry Workers ed. by Factory Department, Ministry of Labour and National Service. H.M.S.O., London.

Heppleston, A. G. (1947). J. Path. Bact., 59, 453.

Hicks, V. McElroy, O., and Warga, M. E. (1937). J. industr. Hyg., $19,177$.

Hunt, A. C. (1956). Thorax, 11, 287.

International Labour Organisation (1953). Proc. Third Internat. Conf. of Experts on Pneumoconiosis, Sydney 1950, vol. 1, p. 124. Geneva.

Jephcott, C. M. (1948). Occup. Med., 5, 701.

Jones, W. R. (1933). J. Hyg. (Lond.), 33, 307.

King, E. J., and Gilchrist, M. (1945). Spec. Rep. Ser. med. Res. Coun. (Lond.), No. 250, Pt. C, p. 21 . H.M.S.O., London.
H. Tep. Coun. (Lond.), No. 250, Pt. C, p. 21 . H.M.S.O., London.
Maguire, B. A., and Nagelschmidt, G. (1956). Brit. J. industr. Maguire, B. A., and Nagelschmidt, G. (1956). Brit. J. industr. Med., 13, 9

_- and Nagelschmidt, G. (1945). Spec. Rep. Ser. med. Res. Coun. (Lond.), No. 250, Pt. B., p. 1. H.M.S.O., London.

Klug, H. P., and Alexander, L. E. (1954). Ẍ-ray Diffraction Procedures for Polycrystalline and Amorphous Materials. Chapman and Hall, London.

Knox, J. F., and Beattie, J. (1954). Arch. industr. Hyg., 10, 23, 30.

Löblich, H. J. (1958). Die Staubiungenerkrankungen, vol. 3, p. 550. Steinkopff, Darmstadt.

Lynch, K. M., and McIver, F. A. (1954). Amer. J. Path., 30, 1117.

Machle, W., Beyer, E. C., and Tebrock, H. (1949). Proc. 9th Internat. Congr. industr. Med., London, 1948, p. 615. John Wright, Bristol.

McLaughlin, A. I. G., and Harding, H. E. (1956). A.M.A. Arch. industr. Hlth, 14, 350.

6, 184. Marks, J., and Nagelschmidt, G. (1959). A.M.A. Arch. industr. Hlth,

Martland, H. S. (1950). In Pneumoconiosis: Leroy U. Gardner Memorial Volume, p. 230. ed. A. J. Vorwald. Höeber, New York.

Mitchell, J. (1959). Brit. J. industr. Med., 16, 123.

Nagelschmidt, G., and King, E. J. (1941). Biochem. J., 35, 152.

Nagelschmidt, G., and (1956). Analyst, 81, 210.

Otto, H., and Einbrodt, H. J. (1958). Frankfurt Z. Path., 69, 404

Rivers, D., Wise, M. E., King, E. J., and Nagelschmidt, G. (1960) D., Wise, M. E., King, E.
Brit. J. industr. Med., $17,2$.

Robertson, J. B., Simson, F. W., and Strachan, A. S. (1937). S. Afr. J. med. Sci., 2, 124.

Sander, O. A. (1958). A.M.A. Arch. industr. Hlth, 17, 96

Schmidt, K. G. (1955). Staub, Heft, 41, p. 436.

Shapiro, L., and Brannock, W. W. (1956). Rapid Analysis of Silicate Rocks. Geol. Surv. Bull. (Wash.), 1036-C.

Simson, F. W. (1931). Proc. Transv. Mine med. Offrs.' Ass. Spec. Suppl., 10, No. 118, p. 1 . and Strachan, A. S. (1935). Publ. S. Afr. Inst. med. Res. (No. 36), 6, 367.

Stegemann, H. and Fitzek J. (1954). Beitr. Silikose-Forsch., Heft, 31, p. 29.

Stewart, M. J., and Faulds, J. S. (1934). J. Path. Bact., 39, 233.

Sundius, N., and Bygdén, A. (1937). Arch. Gewerbepath. Gewerbehyg., $8,26$.

$\overline{\text { Talbot (1959). }}$ (1938). J. industr. Hyg., 20, 351

Thomas, K., and Stegemann, H. (1954). Beitr. Silikose-Forsch., Heft, 28, p. 1 .

Trostel, L. J., and Wynne, D. J. (1940). J. Amer. ceramic Soc. 23, 18 .

Watson, A. J., Black, J., Doig, A. T., and Nagelschmidt, G. (1959).

Wright, B. M. (1957). Ibid., 14, 219. 